\title{
Community Diagnosis Tentang Wabah Penyakit Demam Berdarah Dengue (DBD) di Dusun Kedungpoh Kidul, Nglipar, Gunungkidul
}

\section{Community Diagnosis of Dengue Hemorrhagic Fever (DHF) in Kedungpoh Kidul, Nglipar, Gunungkidul District}

\author{
Suci Musvita Ayu*, M. Reza, Khairunnisa, Rizki Arum M, Ryani Dwi Kurniawati, \\ Dana Kristiani, Dian Utami, Fanimas Tiwi, Cahyaningsih, Nida Alifah \\ Fakultas Kesehatan Masyarakat Universitas Ahmad Dahlan, Yogyakarta, Indonesia \\ suci.ayu@ikm.uad.ac.id
}

Riwayat Artikel: Dikirim 11 Desember 2019; Diterima 15 Mei 2020; Diterbitkan 20 Mei 2020

\begin{abstract}
Abstrak
Demam Berdarah Dengue (DBD) merupakan salah satu penyakit yang menjadi masalah kesehatan lingkungan saat sekarang ini. Kasusnya cenderung meningkat dan semakin luas daerah penyebarannya, Hal ini berbarengan dengan meningkatnya mobilitas dan kepadatan penduduk disuatu daerah. Metode yang digunakan adalah studi penelitian deskriptif kuantitatif untuk mendapatkan gambaran dan keteranganketerangan mengenai kondisi kesehatan terkait Penyakit Demam Berdarah Dengue. Hasil yang diperoleh adalah tingginya angka penyebaran DBD di saat musim penghujan. Kesimpulan prevalensi permasalahan kesehatan yang ada yaitu tingginya angka penyebaran DBD persentase sebesar 25\%.
\end{abstract}

Kata kunci: Demam Berdarah Dengue, Lingkungan, Survei Jentik.

\begin{abstract}
Dengue Hemorrhagic Fever (DHF) is one of the diseases that is currently an environmental health problem. Cases are increasing and spreading more widely. This is coupled with the movement of mobility and population density in an area. The method used is a quantitative descriptive research study to get an overview and information about health conditions related to Dengue Fever. The results obtained are the high rate of spread of DHF in the rainy season. The conclusion of the prevalence of existing health problems is the magnitude of the DHF distribution rate of $25 \%$.
\end{abstract}

Keywords: Dengue Hemorrhagic Fever, Environment, Survey of larvae

\section{PENDAHULUAN}

Penyakit Demam Berdarah Dengue (DBD) adalah masalah masyarakat terutama dalam bidang kesehatan lingkungan yang terus jumlahnya mengalami peningkatan pesat termasuk daerah penyebarannya. Hal ini sejalan dengan peningkatan mobilitas dan kepadatan penduduk. Virus dengue yang dibawa oleh nyamuk Aedes aegypti maupun Aedes albopictus menyebabkan seseorang terkena DBD.

Aedes aegypti aktif dalam penularan penyakit karena berkembangbiaknya di sekitar rumah, baik itu didalam atau diluar. Aedes albopictus hidup di kebun, jadi jarang kontak dengan manusia (Depkes RI, 1992). DBD terdeteksi untuk pertama kali pada tahun 1953 di Filipina. Sedangkan di Indonesia pertama kali kasus terdiagnosis tahun 1968 di Surabaya sebanyak 58 kasus, 24 diantaranya meninggal (Angka Kematian (AK): 41,3\%). Indonesia sendiri tercatat ada 59.047 kasus DBD dan ada 444 kasus meninggal dunia dikarenakan penyakit DBD tersebut. Di daerah Yogyakarta tercatat ada 1.642 kasus penyakit DBD dengan 7 orang meninggal dunia akibat penyakit DBD.

World Health Organization (WHO) menyebutkan bahwa Indonesia merupakan 
negara yang mengalami kasus DBD tertinggi di Asia Tenggara. Indonesia memiliki risiko terjangkit penyakit DBD, kecuali daerah yang memiliki ketinggian lebih dari 1000 meter diatas permukaan laut. Kasus ini masih menjadi perhatian utama baik bagi para pakar/ profesional maupun bagi mahasiswa, mengingat insiden penyakit ini masih terus menunjukkan peningkatan. Selain itu, belum semua masyarakat mempunyai kewaspadaan dini terhadap DBD yang berakibat pada kematian. $\mathrm{Hal}$ ini dipengaruhi dari kondisi lingkungan, mobilitas penduduk, kepadatan penduduk, adanya kontainer buatan ataupun alami di tempat pembuangan akhir sampah (TPA) ataupun di tempat sampah lainnya. Sehingga intervensi yang bisa dilakukan untuk meningkatkan kesadaran masyarakat yaitu dengan penyuluhan dan perilaku masyarakat, antara lain: peningkatan pengetahuan, sikap, kegiatan pemberantasan sarang nyamuk (PSN), fogging, abatisasi dna pelaksanaan 3M Plus.

Berdasarkan kegiatan analisis data yang dilakukan di Dusun Kedungpoh Kidul didapatkan hasil bahwa masyarakat di Dusun Kedungpoh Kidul memiliki pengetahuan yang rendah tentang bagaimana cara pencegahan serta perlindungan terhadap penyakit DBD, sedangkan angka kasus DBD pada musim penghujan di Desa Kedungpoh dapat meningkat. Oleh karena itu kami menjadikan DBD sebagai prioritas masalah kesehatan di Dusun Kedungpoh Kidul.

\section{METODE}

Penelitian ini merupakan studi penelitian deskriptif kuantitatif untuk mendapatkan gambaran dan keteranganketerangan mengenai kondisi kesehatan terkait Penyakit Demam Berdarah Dengue. Dengan analisa prioritas masalah menggunakan skala Likert.

Intervensi yang diberikan untuk mengatasi permasalahan mitra adalah dengan pemeriksaan jentik nyamuk dan pembagiaan bubuk abate pada masyarakat di setiap RT dilakukan selama 3 hari. Standar Operasional Prosedur (SOP) kerja untuk mendukung realisasi metode dilakukan pemeriksaan jentik nyamuk dan pembagian bubuk abate agar masyarakat dapat mengetahui cara mengamati jentik nyamuk dalam kontainer dan aturan pemakaian bubuk abate.

\section{HASIL DAN PEMBAHASAN}

Berdasarkan analisis situasi padukuhan Kedungpoh Kidul dengan pendekatan epidemiologi yaitu waktu, tempat, dan orang didapatkan hasil sebagai berikut:

\section{Waktu}

Kebanyakan masalah timbul di Kedungpoh Kidul berdasarkan waktu yaitu, kejadian cedera yang disebabkan karena kecelakaan lalu lintas ataupun pada saat berkebun. Apabila sedang musim hujan, banyak nyamuk yang masuk ke dalam rumah, tapi tidak pernah terjadi kasus DBD.

\section{Tempat}

Kondisi Kedungpoh Kidul yang belum memiliki TPS menjadikan mayoritas masyarakat Kedungpoh Kidul mengolah sampah dengan cara dibakar dan sampah dibiarkan di tempat terbuka.

\section{Orang}

Mayoritas masyarakat Kedungpoh Kidul masih belum menggunakan perlindungan dan pencegahan yang benar untuk menghindari dari gigitan nyamuk, hal itu dikarenakan masyarakat tidak merasa banyak nyamuk sehingga tidak melakukan perlindungan apapun untuk mencegah penyakit akibat gigitan nyamuk yaitu DBD.

Tidak hanya pendekatan epidemiologi (Waktu, Tempat, dan Orang) yang dilakukan, tetapi ditambah dengan adanya wawancara mendalam untuk mengetahui kondisi kesehatan masyarakat Dusun Kedungpoh Kidul. Masyarakat 
dusun Kedungpoh Kidul telah memiliki jamban, meskipun ada beberapa warga yang masih menggunakan jamban cemplung. Kesadaran masyarakat yang kurang akan pentingnya kesehatan menjadi penghambat program yang dilakukan.Upaya pencegahan terlebih dahulu dilakukan yaitu dengan melakukan check-up rutin dari pihak Puskesmas dan kader lansia. Selain itu adapun karena faktor jalur aksesnya di Dusun Kedungpoh Kidul antar satu RT dan RT lainnya cukup jauh sehingga mengakibatkan masyarakat menjadi tidak antusias untuk ikut serta saat ada pemeriksaa, ditambah lagi kegiatan keseharian masyarakat yang berladang, dan seorang petani yang membuat mereka lebih mementingkan untuk kehdupan dibandingkan melakukan pemeriksaan kesehatan.

Berdasarkan kuesioner yang ada maka dilakukan pengolahan data dengan excel dan dilakukan menggunakan rumus Countif. Setelah dikalkulasi dan dihitung prosentasenya didapati 3 (tiga) persentase masalah teringgi di Dusun Kedungpoh Kidul sebagai berikut :

1. Tingginya angka penyebaran DBD di saat musim penghujan di dusun Kedungpoh Kidul.

2. Tingginya angka cedera di dusun Kedungpoh Kidul dalam kurun waktu satu tahun terakhir.

3. Kurangnya pengetahuan masyarakat mengenai HIV/AIDS di Kedungpoh Kidul.

Penentuan prioritas masalah menggunakan skala likert, dengan melihat faktor-faktor:

1. Tingkat Urgensinya (U/Urgency)

2. Keseriusannya (S/Seriousness)

3. Potensi perkembangannya (G/Growth)
Faktor-faktor bernilai 1 untuk mewakili kejadian sangat kecil sampai skala 5 untuk mewakili kejadian sangat besar. Nilai total digunakan untuk mengurutkan masalah kesehatan berdasar prioritasnya dengan menggunakan persamaan:

\section{$\mathbf{T}=\mathbf{U}+\mathbf{S}+\mathbf{G}$}

Tabel 1:

Penentuan Prioritas Masalah menggunakan USG

\begin{tabular}{|c|c|c|c|c|c|c|}
\hline \multicolumn{7}{|c|}{ Prioritas Masalah Berdasarkan Metode USG } \\
\hline Ż & 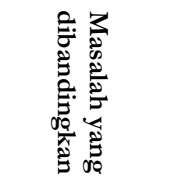 & 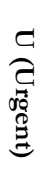 & $\begin{array}{l}\infty \\
6 \\
8 \\
8 \\
5 \\
0 \\
0 \\
0 \\
0\end{array}$ & 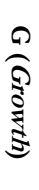 & 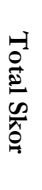 & $\stackrel{\vec{\nu}}{\vec{\Delta}}$ \\
\hline 1 & $\begin{array}{l}\text { Kurangnya } \\
\text { pengetahua } \\
\text { n } \\
\text { masyarakat } \\
\text { mengenai } \\
\text { HIV/AIDS } \\
\text { di } \\
\text { Kedungpo } \\
\text { h Kidul }\end{array}$ & 3 & 2 & $\mathbf{0}$ & 5 & 3 \\
\hline 2 & $\begin{array}{l}\text { Tingginya } \\
\text { angka } \\
\text { penyebaran } \\
\text { DBD di } \\
\text { saat musim } \\
\text { penghujan } \\
\text { di dusun } \\
\text { Kedungpo } \\
\text { h Kidul }\end{array}$ & 4 & 4 & 3 & 11 & 1 \\
\hline 3 & $\begin{array}{l}\text { Tingginya } \\
\text { angka } \\
\text { cedera di } \\
\text { dusun } \\
\text { Kedungpo } \\
\text { h Kidul } \\
\text { dalam } \\
\text { kurun } \\
\text { waktu satu } \\
\text { tahun } \\
\text { terakhir }\end{array}$ & 2 & 3 & 1 & 6 & 2 \\
\hline
\end{tabular}

Sumber: Dokumentasi Pribadi 
Hasil tersebut merupakan hasil dari USG yang telah diisi didasarkan pada skala likert 1-5 (5= Sangat Besar, 4= Besar, 3= Sedang, 2= Kecil, 1= Sangat Kecil) maka didapatkan prioritas masalah yaitu berupa Tingginya angka penyebaran DBD di saat musim penghujan. Hasil yang didapat ini telah diketahui oleh Ketua RT 01, RT 02, RT 03, RT 04, Ketua RW 01, Kepala Dukuh, pihak Puskesmas bagian Promosi Kesehatan dan Dosen Pembimbing Lapangan.

Analisis menggunakan data sekunder dengan pendekatan epidemiologi yang ditemukan di Dusun Kedungpoh Kidul adalah sebagai berikut:

Gambar 1:

Analisis Data Sekunder

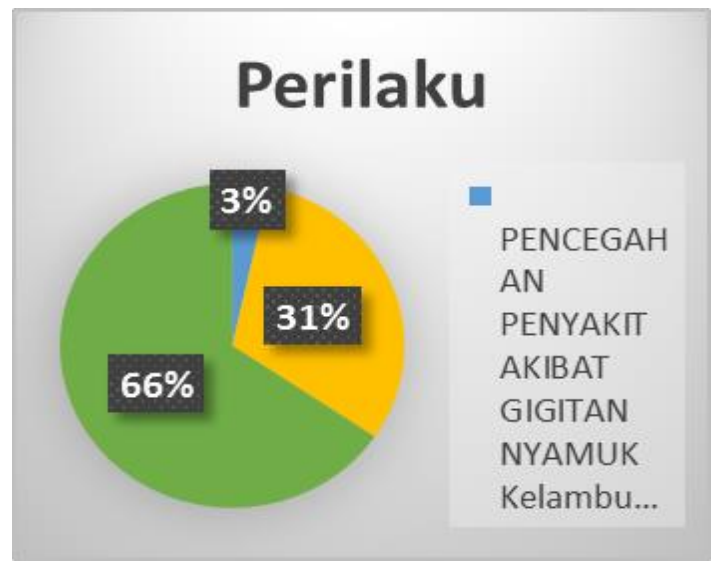

Sumber: Dokumentasi Pribadi

Alternatif pemecahan masalah yang digunakan dalam diagnosis komunitas yaitu analisis SWOT dengan pemecahan masalah berupa pemeriksaan jentik nyamuk dan pembagiaan bubuk abate pada masyarakat di setiap RT. Penjelasan lebih detail terhadap warga masyarakat didusun tersebut juga menjadi solusi. Perkembangan populasi nyamuk Aedes aegypti tidak sebatas penanaman pola perilaku menguras, menutup, dan mengubur $(3 \mathrm{M})$, tetapi juga memikirkan pola lingkungan yang terjadi dalam mendukung program 3M. Perilaku 3M merupakan perilaku perseorangan dalam lingkup masyarakat dan konsep yang lebih universal dalam mencegahnya merupakan bagian dari program pemerintah. Selain dipicu adanya bak-bak penampungan air, nyamuk juga berkembang dengan adanya genangan air akibat volume sampah anorganik yang berlebihan. Sampah itu sering kali menjadi tempat tergenangnya air ketika musim penghujan. Program reuse, reduce, recycle (3R) tidak dapat berjalan ketika konsep nyatanya pun tidak disosialisasikan. Program good health governance bagi pemerintah seharusnya mengedepankan alur berpikir taktis dan solutif melalui pembedahan jenjang permasalahan dan intervensi di setiap level masalahnya.

Setelah didapatkan Prioritas Masalah dn Usulan Progrm Kerja, dilakukanlah Kegiatan Musyawarah Masyarakat Dusun (MMD) dengan mendatangi aparat dusun Kedungpoh Kidul (Ketua RT, RW, Kepala Dukuh, dan Stakeholder). Dengan dilaksanakan MMD, maka usulan program kerja disetujui oleh aparat dusun. Dari ketiga usulan program kerja, maka dilakukan kegiatan yang mengikut sertakan masyarakat.

Gambar 2:

Pengambilan data kuesioner di masyarakat

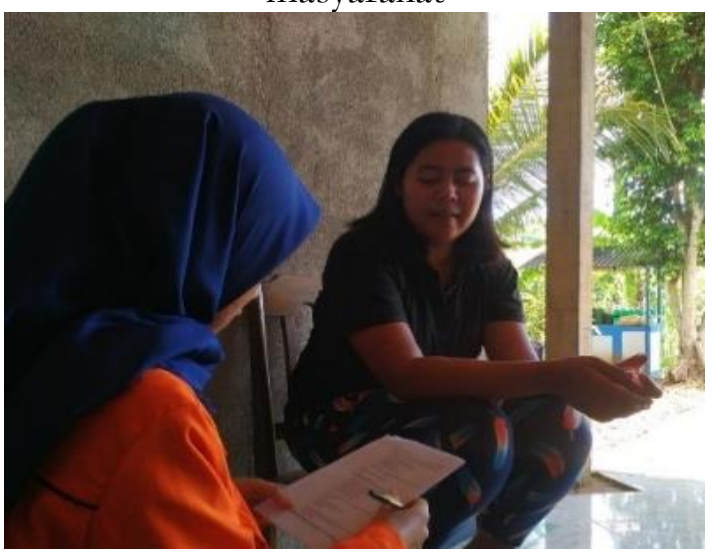

Sumber: Dokumentasi Pribadi 
Gambar 3:

Pemeriksaan Jentik di rumah-rumah warga

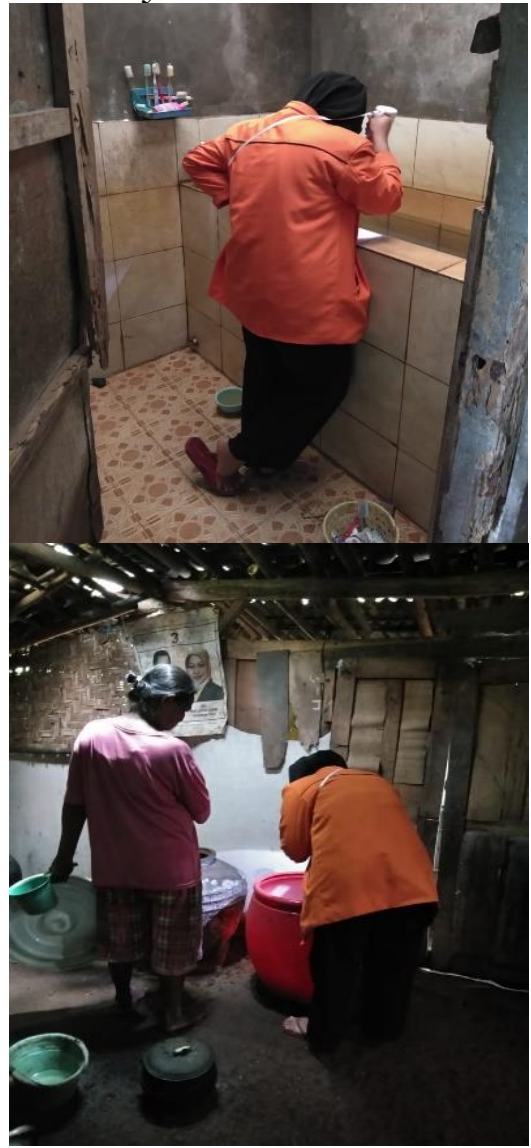

Sumber: Dokumentasi Pribadi

\section{KESIMPULAN}

Berdasarkan identifikasi masalah kesehatan yang ada di dusun Kedungpoh Kidul ditemukan kegiatan PPM di Dusun Kedungpoh kidul dapat berjalan dengan baik dan lancar. Peserta aktif dan kooperatif selama mengikuti kegiatan dengan baik. Hasil lain yang didapat bahwa prevalensi permasalahan kesehatan yang menjadi persentase terbesar yaitu sebesar $25 \%$ dalam kategori tingginya angka penyebaran DBD.

\section{DAFTAR PUSTAKA}

Centre for Desease Control and Prevention (CDC). (2001). Updated Guidlines for Evaluating Public Health Surveilance System. Atlanta.http://www.cdc.gov/mmwr/pre view/.../rr5013a1.htm.

Depkes RI. (2016). Kendalikan DBD

Dengan PSN 3M Plus. Jakarta:
Departemen Kesehatan Republik Indonesia.

Fathi, Kemas S, W. C. (2005). Peran Faktor Lingkungan dan Perilaku Terhadap Penularan Demam Berdarah Dengue di Kota Mataram. Jurnal Kesehatan Lingkungan, 2(!0), (1-10). Surabaya: Kesling UNAIR.

Kementerian Kesehatan RI. (2018). Profil Kesehatan Indonesia 2017. Kementerian Kesehatan Republik Indonesia. Jakarta: Kementerian Kesehatan Republik Indonesia.

Kementerian Kesehatan RI. (2010). Demam Berdarah Dengue. Buletin Jendela Epidemiologi, Volume 2. Jakarta: Pusat Data dan Surveilans Epidemiologi Kementerian Kesehatan RI.

Murti, Bhisma. (2003). Prinsip dan Metode Riset Epidemiologi. Yogyakarta: Gadjah Mada University Press.

Yudhastuti, R., \& Vidiyani, A. (2005). Hubungan kondisi lingkungan, kontainer dan perilaku masyarakat dengan keberadaan jentik nyamuk Aedes aegypti di daerah endemis demam berdarah. Jurnal Kesehatan Lingkungan, 1. https://doi.org/10.3109/03014460.20 12.697578.

Zumaroh, (2015). Evaluasi Pelaksanaan Surveilans Kasus Demam Berdarah Dengue Di Puskesmas Putat Jaya Berdasarkan Atribut Surveilans, Jurnal Berkala Epidemiologi, 3(1), Januari 2015: 82-94

Wilkins A, Nsubuga P, Mendlein J, Mercer D, Pappaioanou M. (2008). The Data for Decision Making Project: Assessment of Surveilance Systems in Developing Countries to Improve Access to Public Health Information.http://www. ncbi.nlm.nih.gov/pubmed/18490035 